УДК 341.231.14:614.4

DOI https://doi.org/10.32837/apdp.v0i85.1826

I. С. Демченко

\title{
ПРАВА ЛЮДИНИ ПІД ЧАС НАДЗВИЧАЙНИХ СИТУАЦІЙ У СФЕРІ ОХОРОНИ ЗДОРОВ’Я
}

Постановка проблеми. 11 березня 2020 року новий коронавірус (Covid-19) був оголошений пандемією [1]. Це означає, що цей новий вірус і захворювання, яке він спричиняє, набув поширення у світових масштабах. А. Гутерреш - генеральний секретар Організації Об’єднаних Націй $(\mathrm{OOH})$ зазначив, що нинішня пандемія - найбільша криза у глобальному здоров'ї протягом останніх 75 років [2]. Захворюванням, яке мало статус пандемії, був "свинячий грип», який тривав 3 2009 по 2010 рік. Чому цей новий коронавірус (далі - Covid-19) викликає стільки страху та як це пов'язано з правами людини?

По-перше, це швидкість його поширення та відсутність лікарських засобів з доведеною клінічною ефективністю (принаймні нині). Підтверджено, що Covid-19 є небезпечним для осіб похилого віку та осіб з хронічними захворюваннями. Ці категорії і так належать до вразливих, а з поширенням Covid-19 їх вразливість збільшується в рази.

По-друге, вразливість національних систем охорони здоров’я. Багато країн вже перевищили свої можливості (матеріальні ресурси та медичний персонал) щодо надання медичної допомоги особам, які її потребують. Філософи та представники біоетики вже почали дискусію щодо визначення пріоритетності у наданні медичної допомоги [3, 4]. В той же час А. Гутерреш зазначає, що «витрати на охорону здоров’я мають бути збільшені для задоволення нагальних потреб при повному дотриманні прав людини та без стигми» [2].

По-третє, безпрецедентні заходи, до яких вдаються країни, з метою захисту здоров’я своїх громадян: закриваються кордони, скасовується авіасполучення, оголошуються режими надзвичайної ситуації. Низка забезпечених правами людини свобод піддається обмеженню. Насамперед це вільне пересування. В Україні двотижнева обсервація українських співгромадян, які прибули з Китайської Народної Республіки, на тлі тисяч осіб, які повернулися з країн Європи та вільно переміщуються всередині країни, викликає щонайменше здивування.

По-четверте, Covid-19 матиме значний вплив на глобальну економіку - сферу виробництва, міжнародну торгівлю, логістику, бізнес. Значна частина людей вимушена підтримувати свій бізнес чи, якщо залишилися без роботи, розраховувати на свої заощадження та соціальну допомогу держав. Соціальна допомога - один з обов'язків держав, який випливає із соціальних прав людини. Держави приймають рішення про зменшення розміру податків, надають пільги та субсидії різним верствам населення

Аналіз останніх досліджень і публікацій. Питання надзвичайних ситуацій у сфері охорони здоров'я (епідемій та пандемій) широко досліджується в медичній науковій літературі, зокрема, у роботах з епідеміології. Щодо дослідження пробле-

(C) I. С. Демченко, 2020 
матики прав людини під час надзвичайних ситуацій у сфері охорони здоров'я, то такі дослідження проводилися здебільшого з точки зору правового регулювання надзвичайного стану, проблематики дотримання прав людини на окупованих територіях, виходячи з положень міжнародного гуманітарного права.

Робіт, присвячених власне питанню дотримання та/або співвідношення прав людини з надзвичайними ситуаціями у сфері охорони здоров'я (епідеміями, пандеміями), досить невелика кількість. Серед наведених напрямів наукового пошуку вирізняються роботи А. Зідара, С. Негрі, М.О. Медведєвої, Г.О. Христової, Н.В. Хендель, О.О. Пунди, Н.I. Орінди. В той же час комплексних досліджень теоретичних і практичних проблем, пов'язаних із забезпеченням прав людини під час надзвичайних ситуацій у сфері охорони здоров'я, не проводилося. Сподіваюся, що це дослідження певною мірою компенсує цей недолік.

Мета статті. Враховуючи зростаючі панічні настрої у суспільстві, безперервний потік інформації з різних джерел, реакції органів державної влади важливо визначити права людини, що діють та підлягають застосуванню під час надзвичайних ситуацій у сфері охорони здоров'я. Відповідно акцент буде зроблений на можливих обмеженнях та відступах від зобов'язань щодо прав людини в інтересах забезпечення громадського здоров'я.

Виклад основного матеріалу дослідження. Слід зазначити, що сучасний світ є глобалізованим. Свобода у пересуванні - можливість протягом доби через авіасполучення потрапити в інше місце на континенті. Covid-19 був виявлений у місті Ухань, провінції Хубєй у Китайській Народній Республіці наприкінці грудня 2019 року. Карантин був введений приблизно через місяць (січень 2020 року), а вже приблизно через три місяці з моменту виявлення факти зараження Covid-19 були підтверджені на всіх континентах. Безумовно, глобалізація стала одним із факторів поширення Covid-19 по всьому світу.

Слід звернути увагу на Міжнародні медико-санітарні правила (далі - ММСП). ММСП за своєю правовою природою є міжнародним договором, обов'язковим документом для всіх держав-членів ООН. ММСП орієнтовані на запобігання найбільш серйозним ризикам у сфері охорони здоров'я транскордонного характеру [5, с. 82]. Саме ММСП визначають, що є «надзвичайною ситуацією у сфері охорони здоров'я, яка має міжнародне значення» - це екстраординарна подія, яка: 1) несе ризик для здоров'я населення в інших державах в результаті міжнародного поширення хвороби; 2) може вимагати скоординованих міжнародних заходів у відповідь [6, с. 1]

Covid-19 відповідає зазначеним ознакам і саме тому належить до «надзвичайної ситуації у сфері охорони здоров'я, що має міжнародне значення». Аналізуючи ММСП, слід зазначити, що заходи на рівні громадського здоров'я мають бути співрозмірні з ризиками для здоров'я населення та обмежені ними, повинні не створювати надмірних перешкод для міжнародних перевезень і торгівлі [6, с. 2]. Саме ця «співрозмірність» і піддається критиці деякими країнами: заходи щодо попередження поширенню Covid-19 є не співрозмірними з наслідками для економіки та суспільства.

Для мети цієї статті важливим є таке положення ММСП, яке «здійснюються 3 повною повагою до гідності, прав людини і основних свобод людей» [6, с. 3]. Ана- 
ліз ММСП дозволяє дійти висновку, що це означає зведення до мінімуму дискомфорту або душевних страждань, включаючи: а) ввічливе і шанобливе поводження 3 усіма особами, які здійснюють поїздку; б) врахування ґендерних, соціально-культурних, етнічних характеристик або релігіозних переконань осіб, які здійснюють поїздку; в) надання або забезпечення продуктами харчування і водою, належними приміщеннями та одягом, охорона багажу та іншого майна, належне медичне лікування, надання необхідних засобів зв'язку, за можливості зрозумілою їм мовою, та іншої належної допомоги для осіб, які здійснюють поїздку, поміщені в карантин або піддані ізоляції, або медичним обстеженням, або іншим процедурам з метою охорони громадського здоров'я. Зазначений підхід дещо відрізняється від більш класичного підходу до розуміння гідності, прав людини та основних свобод.

Якщо ММСП є обов'язковими для всіх держав-членів ООН, то розуміння прав людини в країнах може суттєво відрізнятися. Це залежить від: 1) визнання та гарантування прав людині в тій чи іншій державі (національний контекст); 2) від обсягу зобов'язань, які взяли на себе держави, ратифікувавши ті чи інші міжнародні договори у сфері захисту прав людини (міжнародний контекст - універсальний чи регіональний).

Навіть незалежно від визнання та гарантування прав людини у визначених випадках допускається обмеження прав людини. 3 точки зору теорії міжнародного права захисту прав людини важливими є такі положення: допускається певне обмеження прав людини; допускається обмеження прав людини у надзвичайних ситуаціях; низка прав людини, які не підлягають обмеженню в будь-якому разі. Відповідно і у більшості країн існують законодавчі положення, які допускають обмеження прав людини на час надзвичайних ситуацій, в тому числі надзвичайних ситуацій у сфері охорони здоров'я.

Загалом права людини та питання обмеження прав людини досліджується та дискутується як у науковій літературі, так і під час судових чи адміністративних процедур. Стосовно громадянських і політичних прав, то відповідно до Міжнародного пакту про громадянські та політичні права 1966 року (надалі - МПГПП), державам дозволяється відступати від своїх зобов'язань (п. 1 ст. 4 зазначеного Пакту) у конкретно визначених випадках. При цьому слід чітко розмежовувати, що «обмеження» та «відступ від зобов'язань» - різні речі. Детально це визначено у Сіракузьких принципах обмеження та відступу від положень МПГПП [7].

У контексті пандемії Covid-19 звертаю увагу на положення пар. 25: «Прагнення захистити здоров'я населення може слугувати підставою для обмеження певних прав, якщо державі необхідно прийняти заходи по усуненню серйозної небезпеки здоров'ю населення чи окремих осіб». Важливо, що ці заходи «можуть бути спрямовані безпосередньо на попередження виникнення захворювання чи небезпеку фізичному здоров'ю, на забезпечення нагляду за хворими чи потерпілими» .

Необхідність обмеження тих чи інших прав людини має відповідати таким критеріям [7, par. 10]: а) базуватися на одному з положень, коли таке обмеження визнається допустимим (зазначений п. 25 - «громадське здоров'я»); б) відповідати нагальній потребі держави чи суспільства; в) переслідувати законну мету (захист здоров’я - законна мета); г) бути співрозмірнім цій меті. Стандарт «пропорцій- 
ності» лежить в основі цього тесту на баланс між законною метою та обмеженням прав. Більш конкретно стандарт пропорційності передбачає делікатне рівняння, яке оцінює важливість мети, гарантованого права та сутність посягання [8, с. 507]. Саме «обмеження» найбільше відповідає забезпеченню карантинних заходів, які запроваджуються як в Україні, так і в країнах Свропи та світу.

Відступ (англ. термін derogation - дерогація, в українській науковій літературі також часто застосовується цей термін) - передбачене міжнародним договором право держави відступати від виконання певних договірних зобов'язань під час збройних конфліктів та іншої суспільної небезпеки, яка загрожує життю нації [9, с. 119]. Відступ від прав у зв'язку з надзвичайним положенням можливий лише у випадку виняткової та дійсної або неминучої небезпеки, яка загрожує життю нації. Загроза життю нації - це загроза, яка: а) стосується всього населення, всієї або частини території держави; б) є загрозою для фізичного здоров’я населення [7, par. 39]. Covid-19 відповідає зазначеним ознакам. Станом на 31 березня Арменія, Естонія, Гватемала, Латвія зробили заяву про відступ від зобов'язань відповідно до статті 4 МПГПП [10].

Аналогічне твердження міститься і в Європейській Конвенції про захист прав людини і основоположних свобод. «Під час війни або іншої суспільної небезпеки, яка загрожує життю нації, будь-яка [держава] може вживати заходів, що відступають від ії зобов’язань за цією Конвенцією, виключно в тих межах, яких вимагає гострота становища, і за умови, що такі заходи не суперечать іншим ï зобов'язанням згідно з міжнародним правом» [11]. Станом на 31 березня Арменія, Естонія, Гватемала, Латвія зробили заяву про відступ від зобов'язань відповідно до статті 15 Європейської Конвенції про захист прав людини і основоположних свобод [12].

Щодо соціально-економічних прав, то Міжнародний пакт про економічні, соціальні та культурні права (далі - МПЕСКП) не містить положень, які б дозволяли державам ані обмежувати, ані відходити від взятих на себе зобов'язань. Відступити не можливо під час збройних конфліктів, надзвичайних ситуацій чи природних катастроф [13, par. 18]. Особливістю МПЕСКП права є принцип прогресивної реалізації чи «поступового повного здійснення», як зазначено в частині 1 статті 2 МПЕСКП.

У контексті Covid-19 право на найвищий досяжний рівень фізичного і психічного здоров'я (право на здоров'я) не обмежується, і держави не можуть відступити від своїх зобов'язань. Серед заходів, які повинні вжити держави для його повного здійснення, є запобігання і лікування епідемічних, ендемічних хвороб [14]. Принцип прогресивної реалізації передбачає дотримання та забезпечення державою основних компонентів права на здоров'я: 1) наявність функціонуючої системи охорони здоров'я, закладів охорони здоров'я, товарів і послуг тощо; 2) доступність (в аспекті недискримінації; фізична доступність; економічна доступність) [15]; 3) прийнятність (питання медичної етики); 4) якість (надання допомоги, закладів охорони здоров'я, товарів і послуг) [16].

Конституція України (стаття 64) допускає обмеження окремих прав і свобод «в умовах воєнного або надзвичайного стану із зазначенням строку дії цих обмежень». Серед прав і свобод, які можуть бути обмежені, є і право на охорону здоров'я, медичну допомогу та медичне страхування (стаття 49). Це пов' язано зі специфікою 
вітчизняного розуміння прав людини у сфері охорони здоров'я. Але надзвичайні ситуації у сфері охорони здоров'я - це не лише питання реалізації соціально-економічних прав, а й їх забезпечення. Глобальна економічна кризи 2008 року, міграція з країн Близького Сходу до країн Європи, витрати держав на сферу охорони здоров'я впливають на розуміння соціально-економічних прав людини.

Пропонується ідея не обмеження чи відступу від зобов'язань, а можливість державам застосовувати ретрогресивні кроки “retrogressive steps”. «Якщо заходи жорсткої економії [17] призводять до ретрогресивних кроків, що впливають на реалізацію прав людини, тягар доказування перекладається на держави, які повинні обгрунтувати такі ретрогресивні крокі [18, par. 15]. Держава (державні органи) повинні обгрунтувати вжиті заходи щодо попередження поширення вірусу та заходи, спрямовані на надання необхідного медичного обслуговування.

Держави повинні аргументувати таке:

1) наявність переконливого державного інтересу. Захист здоров'я населення більш ніж переконливий державний інтерес;

2) необхідність, розумність, тимчасовість і пропорційність заходів економії;

3) вичерпання альтернативних та менш обмежуючих заходів. Аргументовано визначити ці критерії при Covid-19 - завдання вкрай важке. Чи є необхідною заборона користування громадським транспортом, крім медичних працівників і працівників комунального господарства, заходом, що відповідає цим критеріям? Чи закриття кордонів і поміщення осіб, які прибули з інших країн, у спеціалізовані приміщення? Чи не була б домашня самоізоляція більш альтернативним заходом?;

4) недискримінаційний характер запропонованих заходів (принцип рівності і заборони дискримінації закріплений як на рівні міжнародних документів, так і в національному законодавстві. Однак під час надзвичайних ситуацій, таких як пандемія, як практично впровадити у життя принцип рівності? Чи не будуть позбавлені найвразливіші верстви населення доступу до апаратів штучної вентиляції легень (що нині визнається одним із ефективних методів лікування при гострих станах від Covid-19). Саме під час пандемії спрацьовують утилітарні ідеї. Завдання прав людини - забезпечити принцип рівності та не допустити будь-які виявів дискримінації;

5) захист мінімальних основних зобов'язань. Саме в контексті забезпечення мінімальних основних зобов'язань виникає протиріччя в контексті раціонального використання медичних ресурсів;

6) участь постраждалих груп та осіб у прийнятті рішень (меншою чи більшою мірою постраждалим є все населення).

Застосування зазначених критеріїв і «ретрогресивних кроків» для соціально-економічних зобов'язань держав під час надзвичайних ситуацій у сфері охорони здоров'я потребує досить обережного підходу. Дії держав повинні базуватися на основі загальноприйнятих стандартів прав людини, унеможливлювати випадки свавільного обмеження прав і свобод людей.

Висновки. Обмеження чи відступ від прав людини в період надзвичайних ситуацій у сфері охорони здоров'я - вимушена міра. На мою думку, наслідки для світової та національної економік ставлять питання щодо співрозмірності та пропорційності заходів, які вживаються країнами у відповідь на попередження Covid-19. 
Хоча ця публікація здебільшого стосувалася обмежень та відступу від прав людини під час Covid-19, в той же час було наголошено, що право на здоров'я як право на найвищий досяжний рівень фізичного і психічного здоров'я діє, а його реалізація потребує першочергової уваги держав. Подолання наслідків Covid-19 буде викликом для держав так само, як і викликом для прав людини.

\section{Jimepamypa}

1. WHO Director-General's opening remarks at the media briefing on COVID-19-11, March 2020. URL: https://www.who.int/dg/speeches/detail/who-director-general-s-opening-remarks-at-the-mediabriefing-on-covid-19---11-march-2020.

2. Guterres A. This is, above all, a human crisis that calls for solidarity. URL: https://www.un.org/en/ un-coronavirus-communications-team/above-all-human-crisis-calls-solidarity.

3. Holm S. A general approach to compensation for losses incurred due to public health interventions in the infectious disease context. Monash Bioethics Review. 2020. URL: https://doi.org/10.1007/ s40592-020-00104-2.

4. Bagenstos S.R. May Hospitals Withhold Ventilators from COVID-19 Patients with Pre-Existing Disabilities? Notes on the Law and Ethics of Disability-Based Medical Rationing. Yale Law Journal Forum. 2020. № 130. (Forthcoming). URL: https://ssrn.com/abstract=3559926.

5. Хендель Н.В. Міжнародно-правове регулювання співробітництва держав у сфері охорони здоров'я: дисертація на здобуття наукового ступеня кандидата юридичних наук: спеціальність 12.00 .11 Міжнародне право. Одеса : Національний університет «Одеська юридична академія», 2014. 200 с.

6. International Health Regulations (2005). Third Edition. WHO, 2016. URL: https://apps.who.int/ iris/bitstream/handle/10665/246107/9789241580496-eng.pdf.

7. The Siracusa Principles on the Limitation and Derogation Provisions in the International Covenant on Civil and Political Rights: UN Commission on Human Rights. 28 September 1984, E/CN.4/1985/4. URL: https://www.refworld.org/docid/4672bc122.html.

8. Zidar A. WHO International Health Regulations and Human Rights: From Allusions to Inclusion. The International Journal of Human Rights. 2015. № 19. P. 505-526. DOI: http://dx.doi.org/10.1080/ 13642987.2015.1045340.

9. Христова Г.О. Відступ держави від зобов'язань у сфері прав людини під час суспільної небезпеки. Visegrad Journal on Human Rights. 2018. № 4 (2). С. 119-126.

10. International Covenant on Civil and Political Rights. Status of Treaties. Status as at: 01-04-2020. URL: https://treaties.un.org/Pages/ViewDetails.aspx?src=TREATY\&mtdsg_no=IV-4\&chapter=4\&clang= -en.

11. European Convention for the Protection of Human Rights and Fundamental Freedoms, as amended by Protocols Nos. 11 and 14: Council of Europe 4 November 1950, ETS 5. URL: https://www.refworld.org/ docid/3ae6b3b04.html.

12. Reservations and Declarations for Treaty № 005 - Convention for the Protection of Human Rights and Fundamental Freedoms. Status as of 01/04/2020. URL: https://www.coe.int/en/web/conventions/ full-list/-/conventions/treaty/005/declarations? $p_{\text {a auth }}=0 \mathrm{C} 00 \mathrm{wpDO}$.

13. Substantive issues arising in the Implementation of the International Covenant on Economic, Social and Cultural Rights: Poverty and International Covenant on Economic, Social and Cultural Rights: Committee on Economic, Social and Cultural Rights. Statement adopted on 4 May 2001. / Geneva, 23 April - 11 May 2001. E/C.12/2001/10. URL: http://www2.ohchr.org/english/bodies/cescr/docs/ statements/E.C.12.2001.10Poverty-2001.pdf.

14. UN General Assembly. International Covenant on Economic, Social and Cultural Rights: UN General Assembly 16 December 1966, United Nations, Treaty Series, vol. 993, p. 3. URL: https://www.refworld.org/docid/3ae6b36c0.html.

15. Демченко I.C. Мінімальні основні зобов'язання держав щодо громадського здоров'я. Актуальні проблеми держави і права. 2018. № 81. С. 35-43.

16. General Comment № 14: The Right to the Highest Attainable Standard of Health (Art. 12 of the Covenant): UN Committee on Economic, Social and Cultural Rights (CESCR). 11 August 2000, E/C.12/2000/4. URL: https://www.refworld.org/docid/4538838d0.html. 
17. Muiznieks N. Human Rights in Europe: from Crisis to Renewal? Council of Europe, 2017. 256 p. URL: https://rm.coe.int/human-rights-in-europe-from-crisis-to-renewal-/168077fb04.

18. Report on austerity measures and economic and social rights: UN Office of the High Commissioner for Human Rights URL: https://www.ohchr.org/Documents/Issues/Development/RightsCrisis/E-2013-82_ en.pdf.

\section{Анотація}

Демченко I. C. Права людини під час надзвичайних ситуацій у сфері охорони здоров'я. - Стаття.

У статті аналізуються положення міжнародних документів в сфері захисту прав людини під час надзвичайних ситуацій у сфері охорони здоров'я. Досліджуються положення Міжнародних медико-санітарних правил щодо забезпечення прав людини, які в силу своєї юридичної природи є обов'язковими для всіх держав-членів ООН. Зазначається, що розуміння прав людини залежить як від ратифікації міжнародних договорів у сфері захисту прав людини (універсального та/або регіонального рівня), так і від положень національного законодавства (визнання та гарантування тих чи інших прав людини).

Проводиться аналіз на відповідність критеріям щодо обмеження прав людини ситуації, яка склалася з пандемією Covid-19. Акцентується увага на принципах співрозмірності та пропорційності заходів при обмеженні або відступі від зобов'язань щодо прав людини в інтересах забезпечення громадського здоров'я. Стверджується, що пандемія Covid-19 відповідає ознакам, які необхідні для відступу від виконання договірних зобов'язань: відступ від прав у зв'язку з надзвичайним положенням можливий лише у випадку виняткової та дійсної або неминучої небезпеки, яка загрожує життю нації. Загроза життю нації це загроза, яка: а) стосується всього населення та всієї або частини території держави; б) несе загрозу для фізичного здоров'я населення.

Право на найвищий досяжний рівень фізичного і психічного здоров'я (право на здоров'я) не обмежується, і держави не можуть відступити від своїх зобов'язань, особливо в контексті Covid-19. Принцип прогресивної реалізації передбачає дотримання та забезпечення державою основних компонентів права на здоров'я: наявності, доступності, прийнятності, якості.

Аналізується можливість застосування державами ретрогресивних кроків реалізації заходів жорсткої економії. Наголошується, що заходи, які застосовують держави, повинні базуватися на основі загальноприйнятих стандартів прав людини та унеможливлювати випадки свавільного обмеження прав і свобод людей.

Ключові слова: громадське здоров'я, право на здоров'я, права людини, міжнародні медико-санітарні правила, соціально-економічне право, обмеження, відступ.

\section{Summary}

Demchenko I. S. Human rights at time of public health emergency. - Article.

This article analyzes the provisions of international human rights instruments in the area of health emergencies. The provisions of the International Health Regulations regarding human rights issues, which is by it's legal nature, is a binding document for all UN Member States, are being investigated. It is noted that understanding of human rights depends on both: ratification of international treaties (universal and regional level) in the field of human rights by each State and national law provisions (recognition and guarantee of certain human rights).

In a context of Covid-19 pandemic, compliance with criteria for limitation of human rights is being analyzed. Principle of proportionality is emphasized. How principle of proportionality is used at limitation or derogation model in the interest of public health. Covid-19 pandemic matches necessary criteria for derogation from international (including ECHR) documents in the sphere of human rights. Derogation measures could be adopted only when faced with a situation of exceptional and actual or imminent danger which treatens the life of nation. A threat to the life of nation is one that: a) affects the whole of the population and either the whole or part of the territory of the State; b) threatens the physical integrity of the population.

The right to the highest attainable standard of physical and mental health (right to health) is not limited and states cannot derogate from their obligations. Especially in the context of Covid-19. The principle of progressive realization involves ensuring compliance and state the main components of the right to health: availability, accessibility, acceptability and quality.

The possibility of states to apply retrograde steps in a time of austerity measures is analyzed. It is emphasized that measures taken by States should be based on generally accepted human rights standards and prevent the arbitrary restriction of human rights and freedoms.

Key words: public health, the right to health, Human Rights, International Health Regulations, Social and economic rights, limitation; derogation. 